\title{
Influence of Periodic Freezing on the Value of the Elastic Modulus of Light-weight Fibre Concrete
}

\author{
O. Pospíchal*, B. Kucharczyková, P. Misák, Z. Hlaváč, T. Vymazal \\ Institute of Building Testing, Faculty of Civil Engineering, Brno University of Technology, Brno, Czech Republic \\ *Corresponding author: pospichal.o@fce.vutbr.cz
}

\begin{abstract}
This paper deals with the influence of periodic freezing on light-weight concrete characteristics. Three different sets of light-weight concrete specimens were periodically freezing and non-destructively tested over time. Another three comparative sets of light-weight concrete specimens were tested at the same time and these sets were placed in water. The main aim was to determine and compare the dynamic elastic modulus values during and after 200 freeze-thaw cycles. The methods for this non-destructive testing were the ultrasonic impulse method and the resonance method.
\end{abstract}

KEY WORDS: Light-weight concrete, freeze-thaw resistance, ultrasonic impulse method, resonance method.

\section{INTRODUCTION}

The freeze-thaw resistance of concrete is related to its air void system and to the bond between the aggregates and matrix. Light-weight aggregate concretes are characterized by specific distribution and the content of air voids in the matrix as well as in the aggregate particles. The main disadvantage of these concretes is their high sensitivity to the curing conditions which can significantly influence the initiation and propagation of cracks. This fact leads to the changes of physical-mechanical, fracture, and durability parameters. One of the approaches to controlling the propagation of cracks is the application of various types of fibre reinforcement in a variety of amounts.

This paper deals with a part of the results of the experimental analysis focused on the freeze-thaw resistance of the light-weight concrete. Polypropylene fibres Forta Econo Net with a length of $38 \mathrm{~mm}$ and $19 \mathrm{~mm}$ were used as a dispersed reinforcement.

\section{COMPOSITION OF LIGHT-WEIGHT CONCRETE}

Fresh concrete mixture was prepared from Liapor 4-8/600 light-weight aggregates (year of delivery 2006), heavy-weight aggregates (DTK) of 0-4 mm fraction, CEM I - $42.5 \mathrm{R}$ cement, fly ash, plasticizer and water. The water and light-weight aggregates of 4-8 mm fraction were dosed by volume, the remaining components by weight. Three mixtures were made: REF, EN38 and EN19. Mixture REF was made without fibres, mixture EN38 
and EN19 differed only in the type of fibres used. The dosage of both was $0.9 \mathrm{~kg} / \mathrm{m} 3$. The composition of the fresh concrete mixture is given in Table 1; workability - flow test was F4 for all prepared mixtures REF, EN38 and EN19.

Table 1: Composition of fresh concrete mixture

\begin{tabular}{|l|l|l|}
\hline Components & Units & Quantities per 1 m3 \\
\hline Liapor 4-8/600 & $\mathrm{m} 3$ & 0.44 \\
DTK 0-4 mm Bratčice & $\mathrm{kg} / \mathrm{m} 3$ & 580 \\
Cement 42.5 R & $\mathrm{kg} / \mathrm{m} 3$ & 400 \\
Fly ash Třinec & $\mathrm{kg} / \mathrm{m} 3$ & 50.0 \\
Plasticizer Sika Viscocrete 1035 & $\mathrm{~kg} / \mathrm{m} 3$ & 5.00 \\
Water & $\mathrm{l}$ & 206 \\
\hline
\end{tabular}

\section{FREEZE-THAW TEST}

The cyclical freezing and thawing of the saturated concrete specimens is the basic testing method for the determination of concrete freeze-thaw resistance (ČSN 73 1322). According to the Czech standard the basic results of this test are, especially, decreases in mass, bending strengths, compressive strengths on the prism's fragments, coefficient of freeze-thaw resistance, and changes of monitored parameters measured with the dynamic NDT method within particular periods. These parameters are mainly used for the determination of the rate of the internal structural damage.

For the experimental analysis two sets of prismatic specimens were used. The first set was exposed to the cyclical freezing and thawing (4 hours freezing and 2 hours thawing). The second set was not frost-attacked (specimens were only immersed in water). Each set contained three different types of LWAC - REF (concrete without fibres), EN38 (concrete with fibres Forta Econo Net $38 \mathrm{~mm}$ ), and EN19 (concrete with fibres Forta Econo Net 19 $\mathrm{mm}$ ). All sets were tested at the same age after which the first set had achieved 200 freezethaw cycles.

\section{EXPERIMENTAL}

\subsection{Testing methods}

The ultrasonic impulse method is widely used for non-destructive determination of the quality of concrete. The method is based on the measurement of the transmission time of an ultrasonic impulse through the tested material. The method is useful in providing information about the uniformity of the concrete, cavities, cracks and defects, the modulus of elasticity, and compressive strength.

The resonance method is intended primarily for detecting significant changes in the dynamic modulus of the elasticity of laboratory or field test specimens that are undergoing exposure to weathering or other types of potentially detrimental influences. The test method may also be used to monitor the development of dynamic elastic modulus with increasing maturity of test specimens. This test method covers measurement of the fundamental transverse, longitudinal, and torsional resonant frequencies of concrete specimens (ASTM International). 

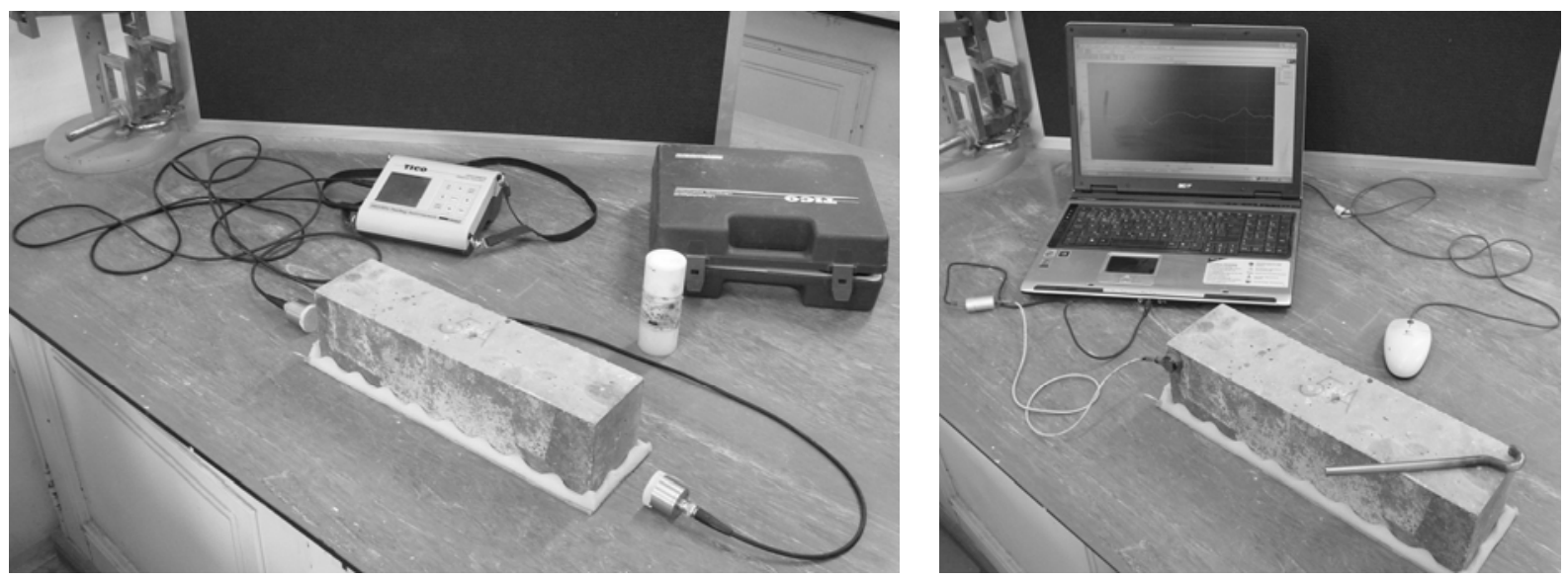

Figure1: Testing equipment - ultrasonic impulse method (left), resonance method (right)

\subsection{Dynamic Modulus of Elasticity}

Internal damage, which can arise during freezing, leads to changes in concrete properties. The volume of the internal damage is related to the value of the dynamic elastic modulus and, according to the Czech standard ČSN 73 1380, it is possible to use two methods to determine the relative dynamic elastic modulus of prismatic specimens. The first method is an ultrasonic impulse method whilst the second is a resonance method.

Both methods are non-destructive testing methods and it is possible to use the following equations for the determination of the relative dynamic elastic modulus:

$$
R D M_{U P P T, n}=\left(\frac{t_{s, 0}}{t_{s, n}}\right)^{2} \times 100 \quad[\%]
$$

where

RDMUPPT,n is the relative dynamic modulus of elasticity evaluated from the ultrasonic impulse method;

$\mathbf{t S , 0}$ is the transmit time of the ultrasonic impulse in [ $\mu \mathrm{s}]$ at a starting measurement;

tS,n is the transmit time of the ultrasonic impulse in [ $\mu \mathrm{s}]$ at a measurement after $\mathrm{n}$ number of the freeze-thaw cycles.

$$
R D M_{F F, n}=\left(\frac{f_{n}}{f_{0}}\right)^{2} \times 100 \quad[\%]
$$

where

RDMFF,n is the relative dynamic modulus of elasticity evaluated from the resonance method; 
fn is the fundamental transverse resonant frequency in $[\mathrm{Hz}]$ at a measurement after $\mathrm{n}$ number of the freeze-thaw cycles;

fo is the fundamental transverse resonant frequency in $[\mathrm{Hz}]$ at the starting measurement.

Both the equations lead to a value that is interpreted as a percentage. It is also possible to express the results of dynamic elastic modulus in specific units according to the Czech standards; ČSN 731371 for the ultrasonic impulse method and ČSN 731372 for the resonance method.

\section{EXPERIMENTAL RESULTS}

Results of the experimental analysis are given in following figures which show their mean values with the standard deviations of the relative modulus of elasticity during and after the freeze-thaw test. The dimensions of the tested specimens were 400x100x100 mm. The number of specimens in each set is presented in Table 2.

Table 2: Number of specimens in each tested set

\begin{tabular}{|l|l|l|}
\hline Type of concrete & Specifications & Amount of specimens \\
\hline \multirow{2}{*}{ REF } & non-frost-attacked & 5 \\
\cline { 2 - 3 } & frost-attacked & 4 \\
\hline \multirow{2}{*}{ EN38 } & non-frost-attacked & 7 \\
\cline { 2 - 3 } & frost-attacked & 6 \\
\hline \multirow{2}{*}{ EN19 } & non-frost-attacked & 6 \\
\cline { 2 - 3 } & frost-attacked & 6 \\
\hline
\end{tabular}

The following three figures show the mean values of the relative dynamic elastic modulus of the three types of the light-weight concrete. The left part of each figure represents values evaluated from the ultrasonic impulse method and the right parts of figures show the results from the resonance method. Every couple of bars in figures there is a comparison of the nonfrost-attacked and the frost-attacked specimens at the same time during the cyclical freezing.
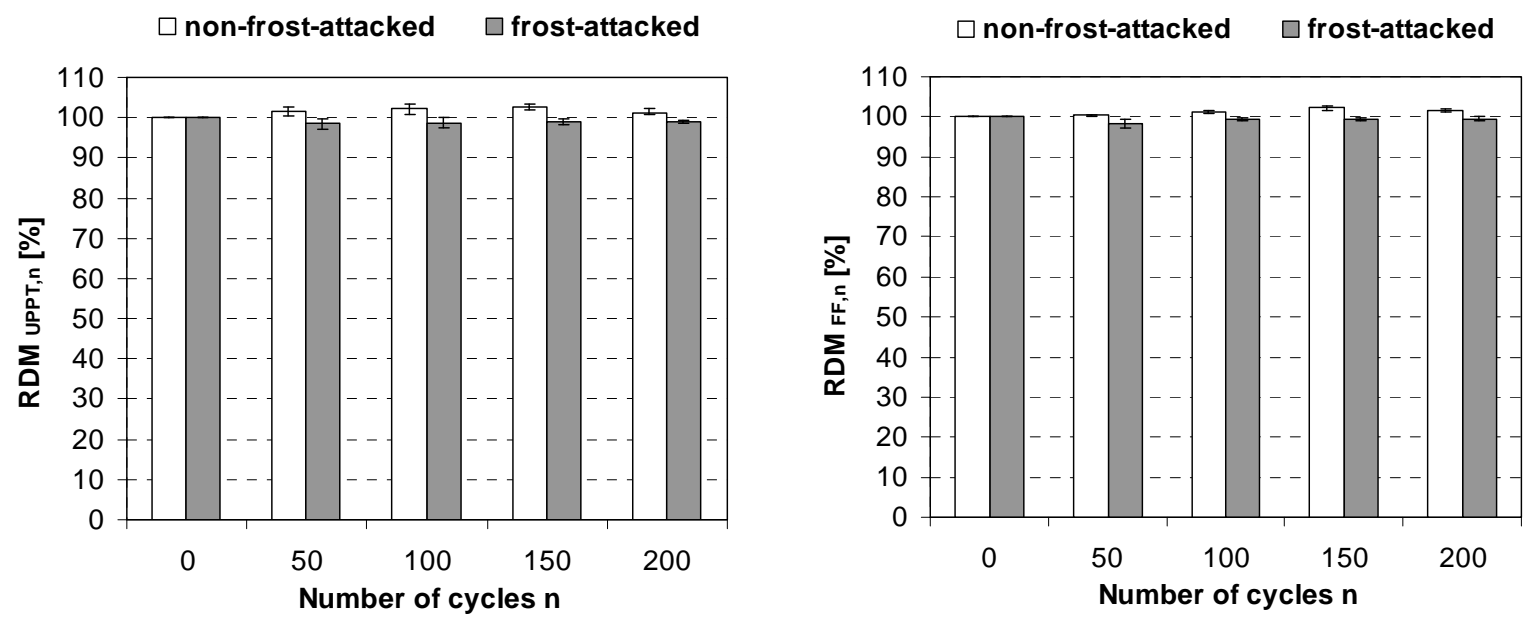

Figure 2: Relative dynamic modulus of elasticity - concrete REF. 
Figure 2 presents results for the concrete REF (without fibres).

Figure 3 presents results for the concrete EN38 (concrete with fibres Forta Econo Net 38 $\mathrm{mm})$.
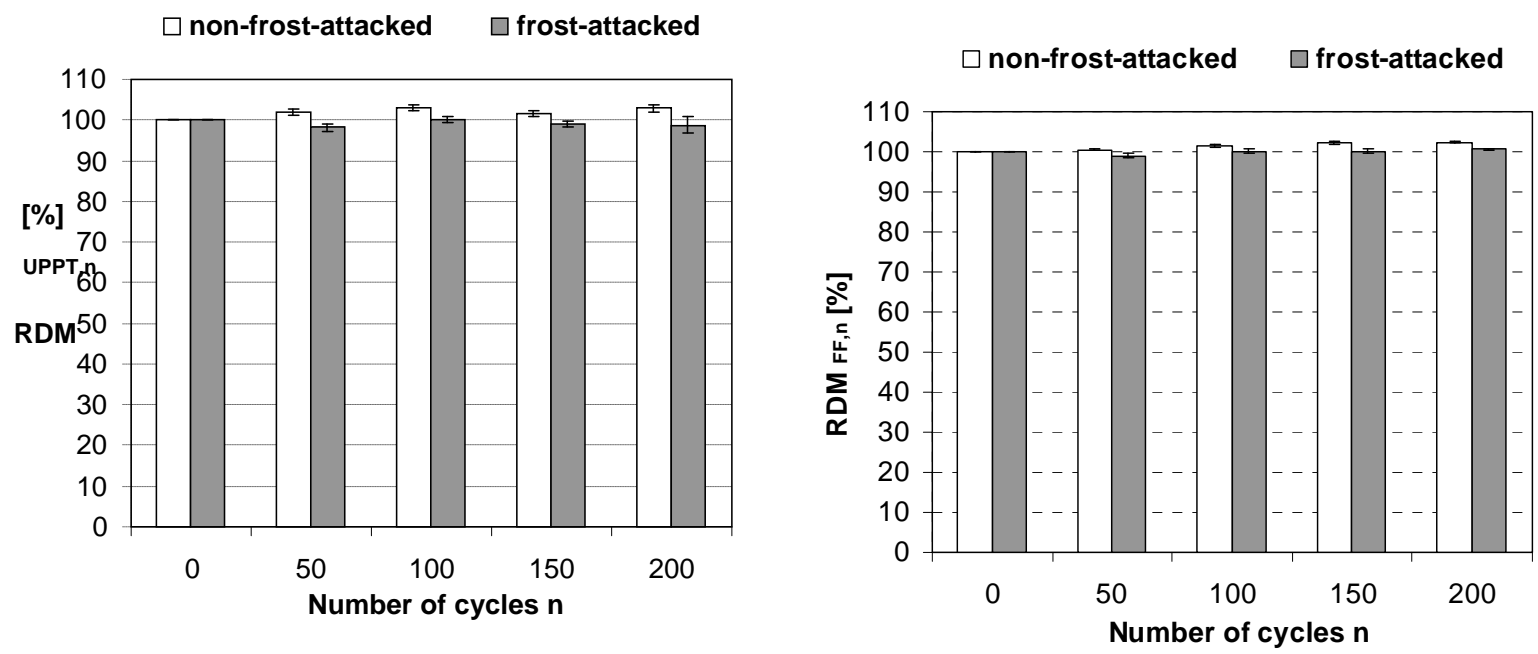

Figure 3: $\quad$ Relative dynamic modulus of elasticity - concrete EN38.

Figure 4 presents results for the concrete EN19 (concrete with fibres Forta Econo Net 19 $\mathrm{mm})$.
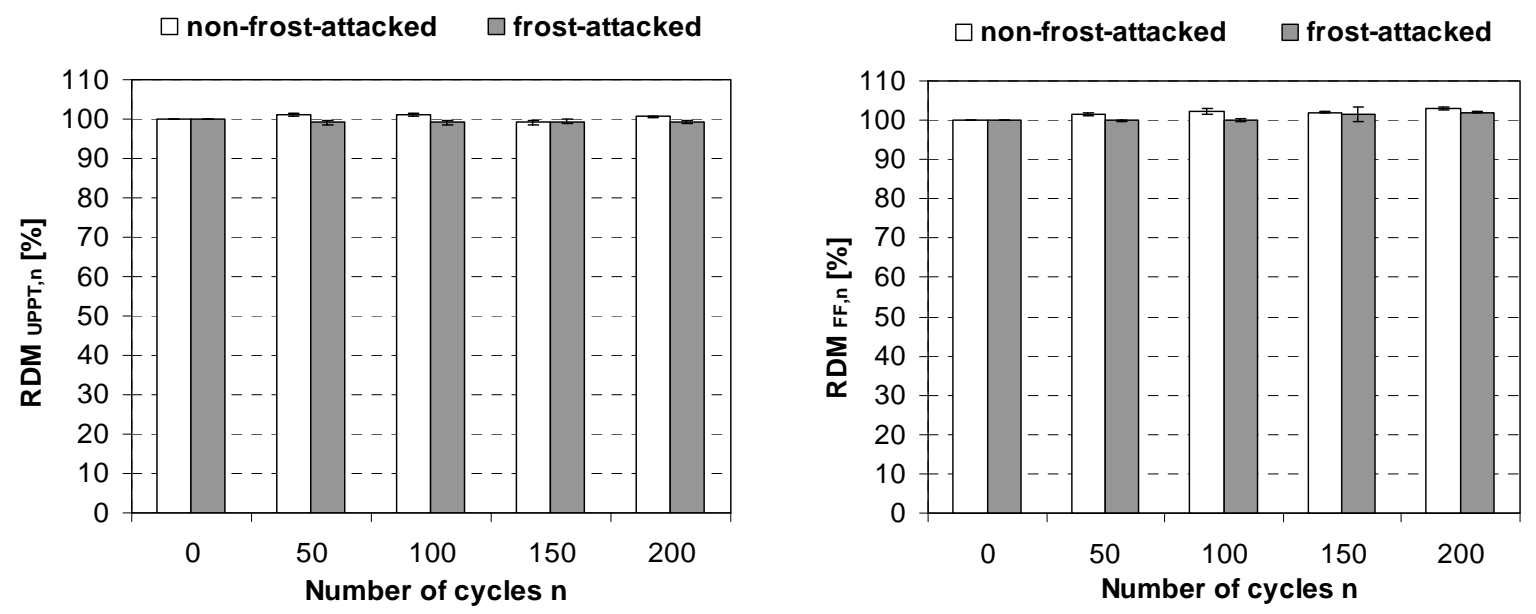

Figure 4: $\quad$ Relative dynamic modulus of elasticity - concrete EN19.

The following two figures show the mean values of the dynamic elastic modulus in specific units GPa of all three types of concrete after 200 freeze-thaw cycles. Figure 5 presents the values evaluated from the ultrasonic impulse method and Figure 6 from the 
resonance method. Every couple of bars in the figures there is a comparison of the non-frostattacked and the frost-attacked specimens after the cyclical freezing.

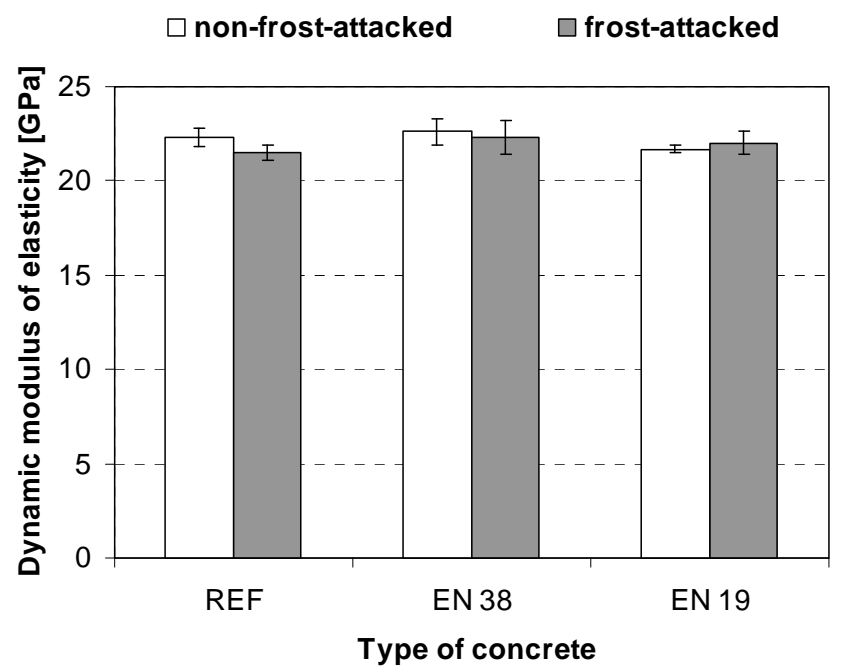

Figure 5: Dynamic modulus of elasticity in GPa evaluated from the ultrasonic impulse method for three types of concrete.

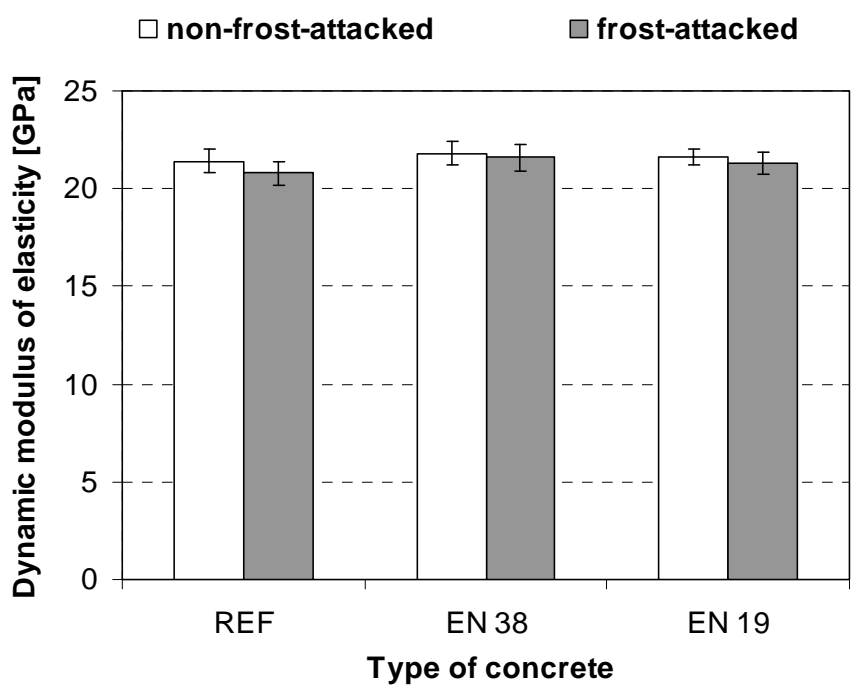

Figure 6: Dynamic modulus of elasticity in GPa evaluated from the resonance method for three types of concrete.

\section{CONCLUSIONS}

From the above-presented results it is possible to conclude:

- The results of both measurement methods are comparable and, unless there are markedly more defects in the structure of the tested specimens, both methods are applicable to evaluate the modulus of elasticity of concrete. 
- All three tested types of concrete are of good enough quality from a freeze-thaw resistance point of view. No mechanical damage or opened cracks on the specimen's surface were observed.

- Frost-attacked specimens show slightly lower values for the modulus of elasticity. Nevertheless, the evaluated values were between 20 and $25 \mathrm{GPa}$ for the frost-attacked specimens, as well as for the non-frost-attacked specimens.

From the performed experiments it is possible to draw the following ideas:

- Non-destructive testing methods - the ultrasonic impulse method and the resonance method - are useful for the evaluation of the dynamic modulus of elasticity and for the monitoring of structural changes in concrete during the freeze-thaw test.

- These methods are insufficient for the description of the total rate of damage of the internal structure in the case of high freeze-thaw resistance concrete.

- For a more detailed overview of material properties it is indispensable to apply more testing methods which are more sensitive to damage by micro-cracks, for example, the determination of the static modulus of elasticity in bending, determination of compressive strength or splitting tensile strength on the prism fragments.

- In recent years the fracture test has been used for a description of material brittleness. The fracture parameters - effective fracture toughness value, work of fracture value complete all above-mentioned characteristics very well.

\section{ACKNOWLEDGEMENT}

This outcome has been achieved with the financial support of the Ministry of Education, Youth and Sports, project No. 1M06005, within the activities of the CIVAK research centre, and the Internal Grant of FCE BUT, project No. VG A52.

\section{REFERENCES}

ČSN 731322 Determination of the concrete freeze-thaw resistance. Czech Standards Institute, 1968.

ČSN 731371 Method of ultrasonic pulse testing of concrete. Czech Standards Institute, 1981.

ČSN 731372 Testing of concrete by resonance method. Czech Standards Institute, 1981.

ČSN 731380 Testing the freeze-thaw resistance of concrete - Internal structural damage. Czech Standards Institute, 2007.

Frantík, P., Keršner, Z.: Vyhodnocení lomového experimentu s katastrofickou ztrátou stability. In: Sborník mezinárodní konference Staticko-konštrukčné a stavebno-fyzikálne problémy stavebných konštrukcií, Štrbské Pleso, 2006, pp. 141-142 (in Czech). 
Hlaváč, Z.; Kucharczyková, B.; Cikrle, P. Light construction Liapor concrete's freeze-thaw resistance. In Proceedings of the International Conference LC2008. Brno, 2008. p. 99 104. ISBN 978-80-214-3773-9.

Kucharczyková, B.; Keršner, Z. Influence of Freeze-Thaw Cycles on Fracture Behaviour of Fibre Reinforced Light-Weight Concrete Specimens. In Proceedings of 5th International Conference Concrete and Concrete Structures. Žilina, 2009. p. 133 - 138. ISBN 978-80554-0100-3.

Veselý, V.: Concrete parameters for description of fracture behaviour. Institute of Structural Mechanics, Faculty of Civil Engineering, Brno University of Technology, Czech Republic: dissertation theses, 2004 (in Czech).

American Society for Testing and Materials (ASTM) web site: www.astm.org 